\title{
Interaction mechanisms and kinetics of ferrous ion and hexagonal birnessite in aqueous systems
}

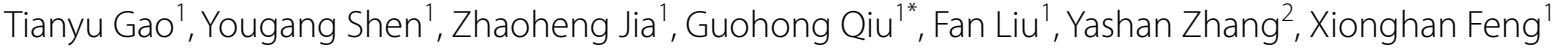 \\ and Chongfa Cai ${ }^{1}$
}

\begin{abstract}
Background: In soils and sediments, manganese oxides and oxygen usually participate in the oxidation of ferrous ions. There is limited information concerning the interaction process and mechanisms of ferrous ions and manganese oxides. The influence of air (oxygen) on reaction process and kinetics has been seldom studied. Because redox reactions usually occur in open systems, the participation of air needs to be further investigated.

Results: To simulate this process, hexagonal birnessite was prepared and used to oxidize ferrous ions in anoxic and aerobic aqueous systems. The influence of $\mathrm{pH}$, concentration, temperature, and presence of air (oxygen) on the redox rate was studied. The redox reaction of birnessite and ferrous ions was accompanied by the release of $\mathrm{Mn}^{2+}$ and $\mathrm{K}^{+}$ ions, a significant decrease in $\mathrm{Fe}^{2+}$ concentration, and the formation of mixed lepidocrocite and goethite during the initial stage. Lepidocrocite did not completely transform into goethite under anoxic condition with pH about 5.5 within 30 days. $\mathrm{Fe}^{2+}$ exhibited much higher catalytic activity than $\mathrm{Mn}^{2+}$ during the transformation from amorphous $\mathrm{Fe}(\mathrm{III})$-hydroxide to lepidocrocite and goethite under anoxic conditions. The release rates of $\mathrm{Mn}^{2+}$ were compared to estimate the redox rates of birnessite and $\mathrm{Fe}^{2+}$ under different conditions.

Conclusions: Redox rate was found to be controlled by chemical reaction, and increased with increasing Fe ${ }^{2+}$ concentration, $\mathrm{pH}$, and temperature. The formation of ferric (hydr)oxides precipitate inhibited the further reduction of birnessite. The presence of air accelerated the oxidation of $\mathrm{Fe}^{2+}$ to ferric oxides and facilitated the chemical stability of birnessite, which was not completely reduced and dissolved after 18 days. As for the oxidation of aqueous ferrous ions by oxygen in air, low and high pHs facilitated the formation of goethite and lepidocrocite, respectively. The experimental results illustrated the single and combined effects of manganese oxide and air on the transformation of $\mathrm{Fe}^{2+}$ to ferric oxides.
\end{abstract}

Keywords: Birnessite, Ferrous ion, Redox, Transformation, Lepidocrocite, Goethite

\section{Background}

The iron redox cycling, particularly $\mathrm{Fe}^{\mathrm{II}}-\mathrm{Fe}^{\mathrm{III}}$ ( $\mathrm{Fe}^{\mathrm{III}}$ and $\mathrm{Fe}^{\mathrm{III}}$ (hydr)oxides), in soils and sediments has obtained a growing concern in the field of soil science, environmental science, and biology, as the redox of $\mathrm{Fe}^{\mathrm{II}}-\mathrm{Fe}^{\mathrm{III}-}$ occurs

\footnotetext{
*Correspondence: qiugh@mail.hzau.edu.cn

${ }^{1}$ Key Laboratory of Arable Land Conservation (Middle and Lower Reaches of Yangtse River), Ministry of Agriculture, College of Resources and Environment, Huazhong Agricultural University, Wuhan 430070, People's Republic of China

Full list of author information is available at the end of the article
}

through either abiotic or biotic pathway in soluble, adsorbed, and solid states [1]. The redox reaction of $\mathrm{Fe}^{\mathrm{II}}-\mathrm{Fe}{ }^{\mathrm{III}-}$ affects the geochemical behavior of minerals and nutrient elements. New experimental evidence shows that $\mathrm{Fe}^{2+}$ induced the release of structural manganese from manganese-doped goethite due to iron oxide recrystallization [2]. Fe(II) can also catalyze the phase transformation from ferrihydrite to goethite and hematite by electron transfer through a dissolution-reprecipitation process $[3,4] . \mathrm{NO}_{3}{ }^{-}$can be reduced by $\mathrm{Fe}(\mathrm{II})$ to form $\mathrm{NH}_{4}^{+}$and magnetite with nitrogen cycle in soils 
and groundwaters [5]. The migration and transformation of pollutants are usually coupled with the redox of $\mathrm{Fe}^{\mathrm{II}}-$ $\mathrm{Fe}^{\mathrm{III}-}$. For example, nitrate strongly influenced arsenic cycling by oxidizing ferrous iron to produce As-adsorbing particulate hydrous ferric oxides under anoxic conditions [6]. The reduction of $\mathrm{U}(\mathrm{VI})$ and the oxidation of ferrous sulfides including pyrrhotite and pyrite are usually catalyzed by $\mathrm{Fe}^{2+}$ as $\mathrm{Fe}^{\mathrm{II}}-\mathrm{Fe} \mathrm{FI}^{\mathrm{III}-}$ cycling works as electron transporter [7-9]. Fe-oxide formation and further transformation affect the uptake and release of cerium and uranium in $\mathrm{Fe}(\mathrm{II} / \mathrm{III})$ aqueous solutions, and it is also found that trivalent actinides and lanthanides are released when dissimilatory iron reduction of $\mathrm{Fe}(\mathrm{III})$-oxides leads to the formation of green rust. However, under oxidizing conditions, green rust may influence radionuclide mobility by catalyzing their transformation to a higher oxidation state [10]. These redox cycles of $\mathrm{Fe}^{\mathrm{II}}-\mathrm{Fe}^{\mathrm{III}-}$ were sometimes derived by biogeochemical pathway $[1,11]$. Therefore, a comprehensive attention has been given for the oxidation of $\mathrm{Fe}(\mathrm{II})$ in environment system.

As one of the most important natural constituents in soils and sediments, manganese oxide minerals with various crystal structures exhibit excellent oxidation and adsorption capacity for organic pollutants and toxic metallic ions [6, 9, 12-16]. Manganese oxides are determined to participate in the oxidation of ferrous ions and the formation of ferric oxides [6, 13, 17]. Fe(II) usually works as catalyst and electron transfer mediator in the oxidation of ferrous sulfides and others [6,9]. However, there are few researches on the interaction process and mechanisms of ferrous ions and manganese oxides, particularly birnessite.

Manganese oxides participated in the oxidation of ferrous ions to form ferric oxides. The oxidation rates of ferrous ions by pyrolusite and $\gamma-\mathrm{MnO}_{2}$ were compared in sulfate solution, and the influence factors of acidity and particle size were considered, indicating that oxidation rate increased about 2 times when pyrolusite was substituted by $\gamma-\mathrm{MnO}_{2}$ [18]. Birnessite, formed from microbial oxidation of $\mathrm{Mn}(\mathrm{II})$, is often enriched with heavy metals and alkaline and alkali earth metals, and generally exhibits the highest oxidation activity and largest adsorption capacity $[2,12,13,16,19]$. The oxidation of Fe(II), such as ferrocyanide and $\mathrm{Fe}^{2+}$, by birnessite was also studied, and the influence of $\mathrm{pH}$ and temperature on the release rate of $\mathrm{Mn}^{2+}$ was considered [20, 21]. Column experiment was conducted to study the reduction of Mn-oxides by ferrous ions in a flow system, and reactive transport modeling was used to analyze, quantify, and elucidate the different reaction controls and their interaction, and it was found that the release of newly formed $\mathrm{Fe}^{3+}$ and $\mathrm{Mn}^{2+}$ would be retarded as they would be first adsorbed on the surface of manganese oxides [22]. During the redox process, initial reduction rates were much faster than long-term rates because of the inhibition by $\mathrm{Fe}(\mathrm{III})$ precipitates in the later stage at higher $\mathrm{pH}$ [23]. The above researches focus on reaction kinetics, which is usually based on the deduced reaction process. However, limited information is available for the interaction process and mechanisms of ferrous ions and manganese oxides, especially for the transformation processes of ferric oxides.

Transition metal ions affected the transformation of ferric oxides with different crystal structures. The presence of $\mathrm{Ni}(\mathrm{II})$ and $\mathrm{Pb}(\mathrm{II})$ inhibited the transformation of amorphous iron oxide into a more crystalline form [24, 25]. $\mathrm{Mn}(\mathrm{II})$ participates in the transformation of ferric oxides, because $\mathrm{Mn}$ (II) substitution would increase the cell volumes and decrease the degree of crystallinity of goethite; in addition, dissolution and recrystallization subsequently occurred [26]. During the oxidation of ferrous ions by birnessite, $\mathrm{Mn}$ (II) would be released and affect the formation process of ferric oxides. The further transformation of ferric oxides and manganese oxides needs to be intensively studied in detail, especially with regard to the influence of the released $\mathrm{Mn}$ (II) and Fe(II) on the formation of ferric oxides.

In the supergene environment, oxygen usually participates in the redox behaviors of active substances. The adsorbed $\mathrm{Mn}(\mathrm{II})$ could also catalyze the oxidation of $\mathrm{Cr}(\mathrm{OH})_{3}(\mathrm{~s})$ to toxic $\mathrm{Cr}(\mathrm{VI})$ in air [27]. The presence of oxygen improves the chemical stability of manganese oxides during the reduction process [28]. Sometimes, this redox reaction was only tested in acidic environment with anoxic conditions. The influence of air (oxygen) on reaction process and kinetics of birnessite and ferrous ions was seldom investigated. Because the redox reactions usually occur in open systems, the participation of air also needs to be further studied.

This work aims for the better understanding of the interaction mechanisms and kinetics of ferrous ion and hexagonal birnessite in aqueous systems. The transformation of synthesized birnessite and ferrous ions during the reaction process and the influences $\mathrm{pH}$, temperature, and concentration on reaction rate were studied. The admission of air into reaction solution is to simulate the aerobic environment in open system. The catalysis of $\mathrm{Fe}^{2+}$ and $\mathrm{Mn}^{2+}$ in the transformation from amorphous $\mathrm{Fe}(\mathrm{III})$-hydroxide to lepidocrocite and goethite were also investigated in nitrogen atmosphere.

\section{Experimental}

\section{The synthesis of birnessite}

Birnessite was synthesized through the reduction of potassium permanganate by concentrated hydrochloric acid [29]. $\mathrm{KMnO}_{4}$ of $31.61 \mathrm{~g}$ was dissolved in $300 \mathrm{~mL}$ deionized water in a conical flask and boiled with an 
oil-bath heated at $100{ }^{\circ} \mathrm{C}$, and then $60 \mathrm{~mL}$ of $6 \mathrm{~mol} \mathrm{~L}^{-1}$ hydrochloric acid was added dropwisely to the boiling solution at $0.7 \mathrm{~mL} \mathrm{~min}^{-1}$ with vigorous stirring. The reaction lasted for $30 \mathrm{~min}$, and then the suspension was aged for $12 \mathrm{~h}$ at $60{ }^{\circ} \mathrm{C}$. The as-obtained mineral was washed with deionized water until filtrate conductivity was below $20.0 \mu \mathrm{S} \mathrm{cm}^{-1}$, and subsequently dried in an oven at $60{ }^{\circ} \mathrm{C}$, and birnessite was prepared and used in the subsequent redox experiments.

\section{The redox of birnessite and ferrous ions}

$\mathrm{FeSO}_{4} \cdot 7 \mathrm{H}_{2} \mathrm{O}$ of $0.5561,1.1121$ and $2.2242 \mathrm{~g}$ was dissolved into $200 \mathrm{~mL}$ distilled deionized water, and the concentration of $\mathrm{Fe}^{2+}$ was about 10,20 , and $40 \mathrm{mmol} \mathrm{L}^{-1}(\mathrm{mM})$, respectively. The reactor was continuously purged with high purity nitrogen gas (99.999\%, Wuhan Iron and Steel (Group) Corp., China). Nitrogen pressure inside the reactor was maintained to be slightly higher than atmospheric pressure to further prevent air ingress. The as-prepared birnessite of $0.2 \mathrm{~g}$ was then added to $\mathrm{FeSO}_{4}$ solution with stirring. The $\mathrm{pHs}$ of reaction systems were controlled at 4.0, 5.5 and 7.0, respectively, using $\mathrm{NaOH}$ and $\mathrm{H}_{2} \mathrm{SO}_{4}$ of $1.0 \mathrm{~mol} \mathrm{~L}{ }^{-1}$. After a period of reaction, about $3.0 \mathrm{~mL}$ solution was filtered through a $0.22-\mu \mathrm{m}$ microporous membrane filter. The solid products and dissolved components in filtrate were respectively characterized to analyze reaction mechanism. To simulate the open system, air was admitted into the reaction solution instead of nitrogen.

To study the influence of $\mathrm{Fe}^{2+}$ and $\mathrm{Mn}^{2+}$ on the formation and further transformation of ferric oxides, $\mathrm{Fe}_{2}\left(\mathrm{SO}_{4}\right)_{3}$ of $8.0 \mathrm{~g}$ was dissolved into $200 \mathrm{~mL}$ distilled deionized water in nitrogen atmosphere, and $\mathrm{MnSO}_{4}$ or $\mathrm{FeSO}_{4}$ was then added at a concentration of $10 \mathrm{mmol} \mathrm{L}^{-1}$, respectively, and $\mathrm{pH}$ was controlled at 5.5. To investigate the oxidation process of ferrous ions in the presence of air, air was admitted into $200 \mathrm{~mL} \mathrm{FeSO}_{4}$ solution of $20 \mathrm{mmol} \mathrm{L}^{-1}$ at $\mathrm{pH} 5.5$ and $\mathrm{pH} 7.0$, respectively. After filtration, the filtrates and precipitates were respectively characterized at different times.

\section{Characterization methods}

The concentration of ferrous ions in filtrate was directly determined by ultraviolet-visible spectrophotometry (UV-1800, Shanghai Mapada Instruments Co., Ltd., China). The filtrate could be first reduced by oxammonium hydrochloride, and then $\mathrm{Fe}^{2+}$ concentration was measured as the total concentration of $\mathrm{Fe}^{2+}$ and $\mathrm{Fe}^{3+}$, and $\mathrm{Fe}^{3+}$ concentration could be obtained by subtraction. The total concentration of $\mathrm{Fe}^{2+}$ and $\mathrm{Fe}^{3+}$ in reaction system and manganese content in samples were also quantified by atomic absorption spectroscopy (Varian AAS240FS). The average oxidation state (AOS) of manganese was measured by an oxalic method [30]. The content of $\mathrm{K}$ in samples and released $\mathrm{K}^{+}$concentration in filtrate was determined by flame photometer (HG-3 blaze photometer). BET surface area of as-obtained birnessite was analyzed by Micromeritics ASAP2020 using nitrogen adsorption measurements. All chemical analysis for each sample was repeated three times.

After a period of reaction time, about $3.0 \mathrm{~mL}$ solution in reaction system was drawn off and filtered through a $0.45-\mu \mathrm{m}$ microporous membrane filter. The wet solid products were soon identified by X-ray diffraction spectrometry (XRD, Bruker D8 Advance diffractometer with $\mathrm{Cu} \mathrm{K} \alpha$ ) at a scan rate of $4^{\circ} \mathrm{min}^{-1}$. Before and after redox reactions, their morphologies were characterized by scanning electron microscopy (SEM, JEOL, JSM-6700F Field Emission) and transmission electron microscopy (TEM, Hitachi, H-7650). Fourier transform infrared spectroscopy (FTIR, Nicolet 8700) was used to characterize the functional group of redox products with a DTGS detector by making pellets with $\mathrm{KBr}$ powder. The contents of crystal water in birnessite were calculated from the mass balance using thermo-gravimetric analysis (TGA) with NETZSCH TG 209 thermal analysis system.

\section{Results and discussion}

The oxidation of $\mathrm{Fe}^{2+}$ by birnessite under anoxic condition Figure 1a shows the XRD patterns of as-prepared hexagonal birnessite, and the detectable five peaks were consistent with JCPDS No. 86-0666, indicating that purephased birnessite was formed. As for hexagonal birnessite, typical three-dimension hierarchical microspheres composed of disk-shaped plates were observed as shown in Fig. 1b. The AOS of birnessite was titrated to be 3.85, and the chemical formula for birnessite was defined as $\mathrm{K}_{0.23} \mathrm{MnO}_{2.03} \cdot 0.6 \mathrm{H}_{2} \mathrm{O}$. The specific surface area of asobtained birnessite was found to be $27.8 \mathrm{~m}^{2} \mathrm{~g}^{-1}$.

The redox reaction was conducted in nitrogen atmosphere to create an anoxic condition at $\mathrm{pH} 5.5$, and solid products were characterized by XRD at different times as shown in Fig. 2. After 5 min of reaction, a mixture of birnessite and amorphous ferric oxides was formed, and then lepidocrocite $(\gamma$-FeOOH, JCPDS No. 76-2301) was formed after $2 \mathrm{~h}$. Birnessite was completely reduced due to the disappearance of characteristic diffraction peaks after 2 days as shown in Fig. 2. The increase of diffraction peaks of goethite ( $\alpha$-FeOOH, JCPDS No. 81-0464) and a relative weakening of lepidocrocite is possibly due to the transformation from lepidocrocite to goethite after 8 days. The transformation from lepidocrocite to goethite in the nucleation process was influenced by multiple factors [31, 32]. This transformation would be inhibited by traces of silicate, aluminate and stannate [32], and markedly interfered by $\mathrm{Ti}(\mathrm{IV}), \mathrm{Cu}(\mathrm{II}), \mathrm{Cr}(\mathrm{III})$ 

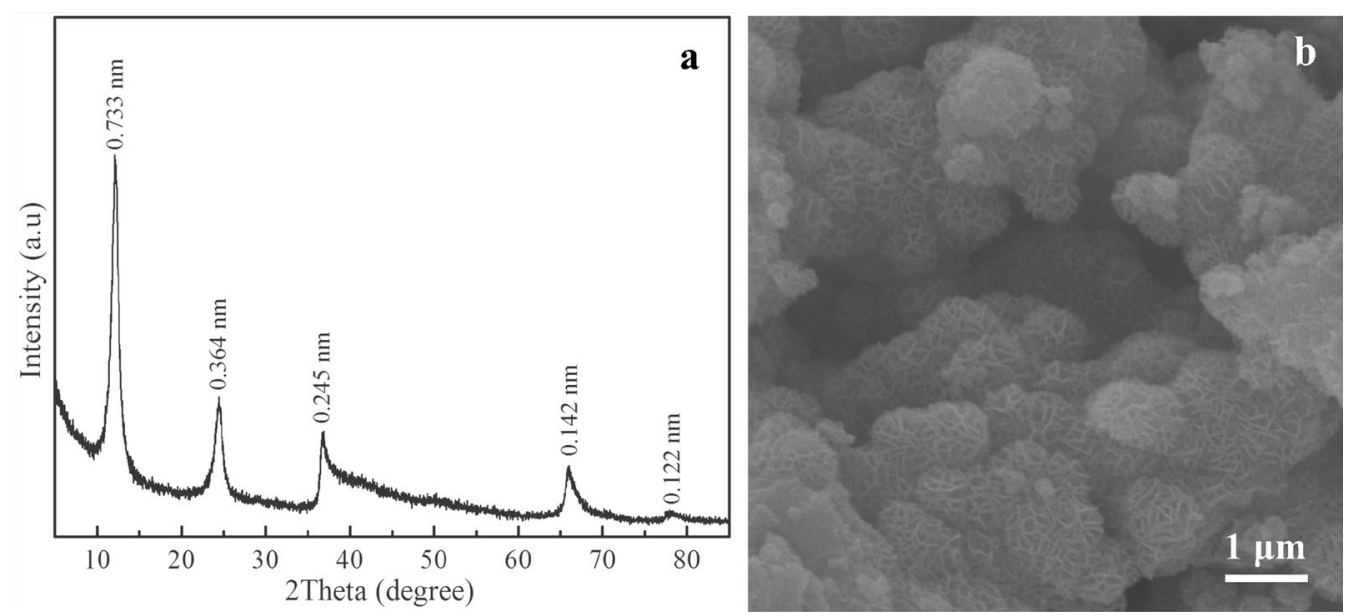

Fig. 1 XRD patterns (a) and SEM image (b) of synthesized birnessite dried at $60^{\circ} \mathrm{C}$ for $24 \mathrm{~h}$
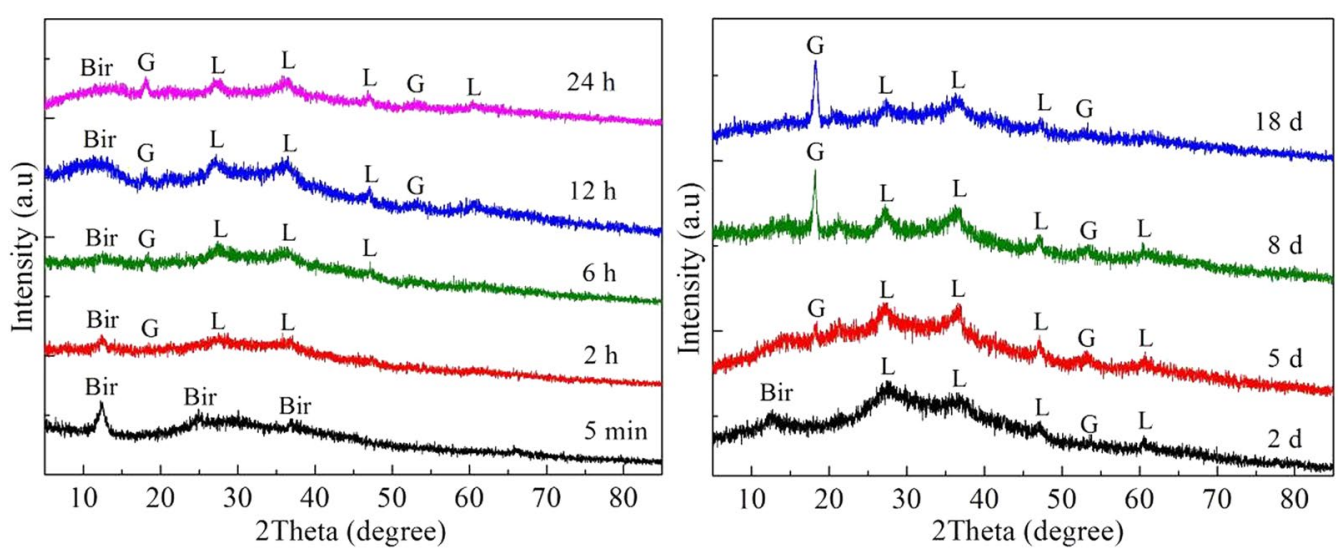

Fig. 2 XRD patterns of solid products of $20 \mathrm{mM} \mathrm{Fe}^{2+}$ oxidized by $1.0 \mathrm{~g} \mathrm{~L}^{-1}$ birnessite with $\mathrm{pH} 5.5$ in nitrogen atmosphere at different times

and $\mathrm{Ni}(\mathrm{II})$, and the coexistence of $\mathrm{Fe}(\mathrm{II})$ and $\mathrm{SO}_{4}^{2-}$ is necessary for this transformation [31]. In the current system, both $\mathrm{SO}_{4}{ }^{2-}$ and $\mathrm{Fe}^{2+}$ participated in the reaction, and the transformation from lepidocrocite to goethite occurred. However, the transformation from relatively metastable lepidocrocite to goethite is extremely slow at ambient temperature [33]. The presence of $\mathrm{Mn}^{2+}$ and other transition metal ions likely assisted this progress, and the newly released $\mathrm{Mn}^{2+}$ could incorporate in goethite [2, 31-33]. Conversely, aqueous $\mathrm{Fe}^{2+}$ can induce the release of structural manganese from manganese-doped goethite [2].

The chemical compositions of solid products were further characterized using FTIR spectroscopy as shown in Fig. 3a. These bands at 467 and $514 \mathrm{~cm}^{-1}$ were assigned to $\mathrm{Mn}-\mathrm{O}$ lattice vibrations of birnessite, and the absorption band around $969 \mathrm{~cm}^{-1}$ was likely due to the bending vibration of $\mathrm{Mn}(\mathrm{III} / \mathrm{IV}) \mathrm{OH}$, which faded and disappeared after 10 days owing to the complete reduction and dissolve of birnessite [34, 35]. The dominant absorption peaks at 1635 and $3423 \mathrm{~cm}^{-1}$ were assigned to the stretching and bending vibrations of crystal water and adsorbed water, respectively [35]. These absorption peaks at $806,1020,1116 \mathrm{~cm}^{-1}$ are attributed to lepidocrocite, and peaks at 619,879 , and $1020 \mathrm{~cm}^{-1}$ are assigned to goethite $[31,36]$. A dominant absorption band at $3139 \mathrm{~cm}^{-1}$ was possibly due to the vibration of hydroxyl group in $\alpha-\mathrm{FeOOH}$ [36]. The increase in the intensity of peaks at $619,879,1020$, and $3139 \mathrm{~cm}^{-1}$ suggested an increase in the content of goethite in solid products. The results further suggested that an incomplete transformation occurred and a mixed phase of lepidocrocite and goethite was formed.

The transformation process was further verified by the change of particle morphology observed by SEM and 

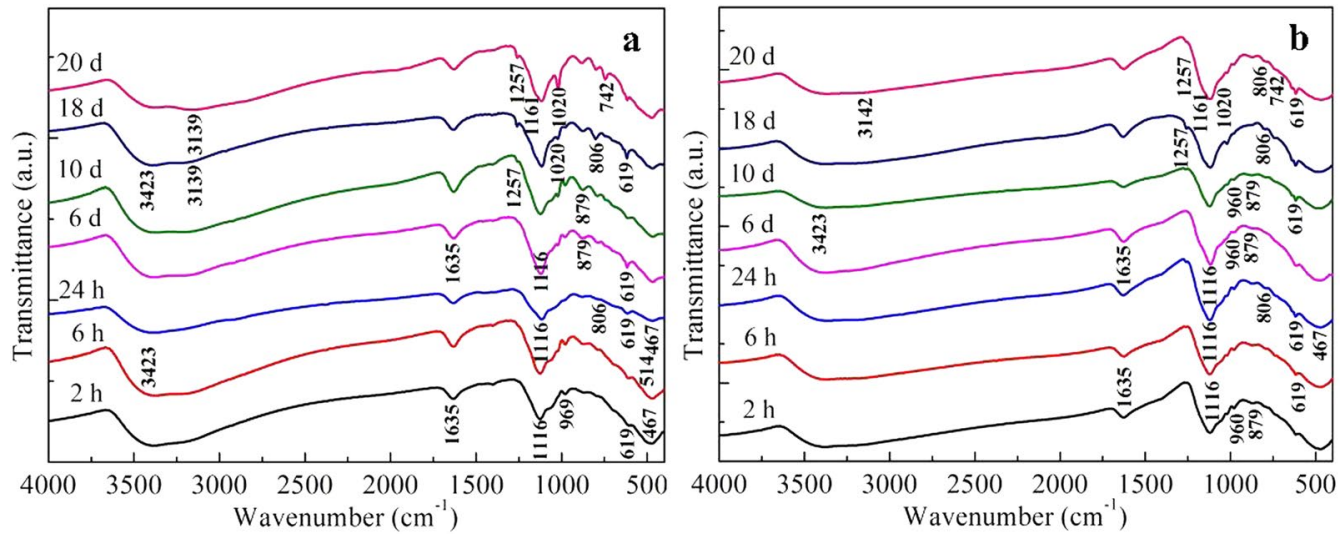

Fig. 3 FTIR spectra of solid products of $20 \mathrm{mM} \mathrm{Fe}{ }^{2+}$ oxidized by $1.0 \mathrm{~g} \mathrm{~L}^{-1}$ birnessite with pH 5.5 in nitrogen atmosphere (a) and air (b) at different times

TEM as shown in Fig. 4a-c. Flower-like birnessite and uniform platelet lepidocrocite particles were observed after $12 \mathrm{~h}$ of reaction (Fig. 4a), which was further confirmed by TEM after ultrasonic dispersion, and goethite was almost absent (Fig. 4b). These results implied that lepidocrocite was formed during the initial stage. After 20 days, the proportion of needle-like goethite particles increased, and flower-like birnessite particles disappeared (Fig. 4c). The similar morphologies were observed during the transformation of lepidocrocite to goethite [31, 32, 37]. These results further indicated that this transformation was too slow to obtain single-phased goethite.

During the reaction process, the concentration of $\mathrm{Fe}^{2+}, \mathrm{Mn}^{2+}$ and $\mathrm{K}^{+}$was quantified as shown in Fig. 5a. It was observed that $\mathrm{Fe}^{2+}$ concentration decreased significantly from $1120 \mathrm{mg} \mathrm{L}^{-1}$ in the initial stage to about $150 \mathrm{mg} \mathrm{L}^{-1}$ at $720 \mathrm{~min}$, and the released $\mathrm{Mn}^{2+}$ and $\mathrm{K}^{+}$concentration increased to 420 and $68.5 \mathrm{mg} \mathrm{L}^{-1}$,

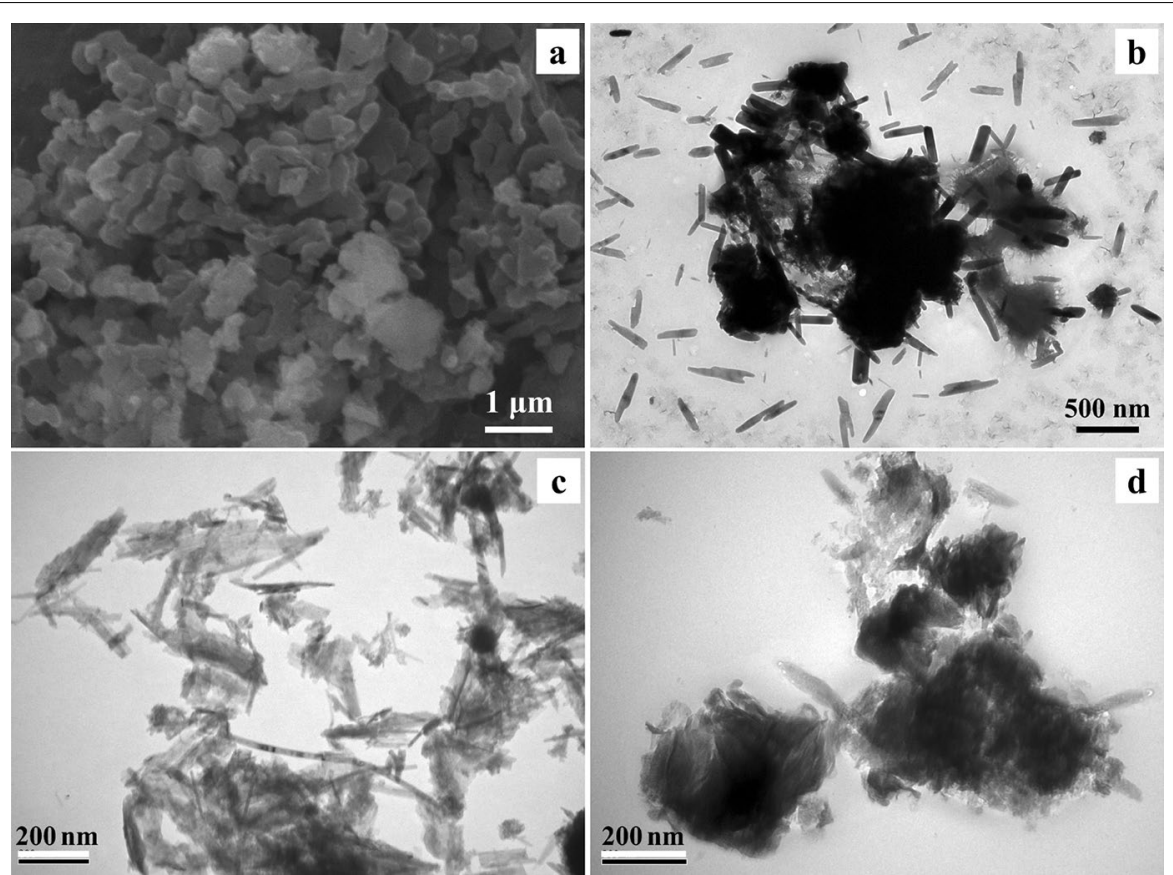

Fig. 4 SEM and TEM images of solid products of $20 \mathrm{mM} \mathrm{Fe}^{2+}$ oxidized by $1.0 \mathrm{~g} \mathrm{~L}^{-1}$ birnessite at $12 \mathrm{~h}(\mathbf{a}, \mathbf{b})$ and 20 days (c) in nitrogen atmosphere, and in air at 20 days (d) 

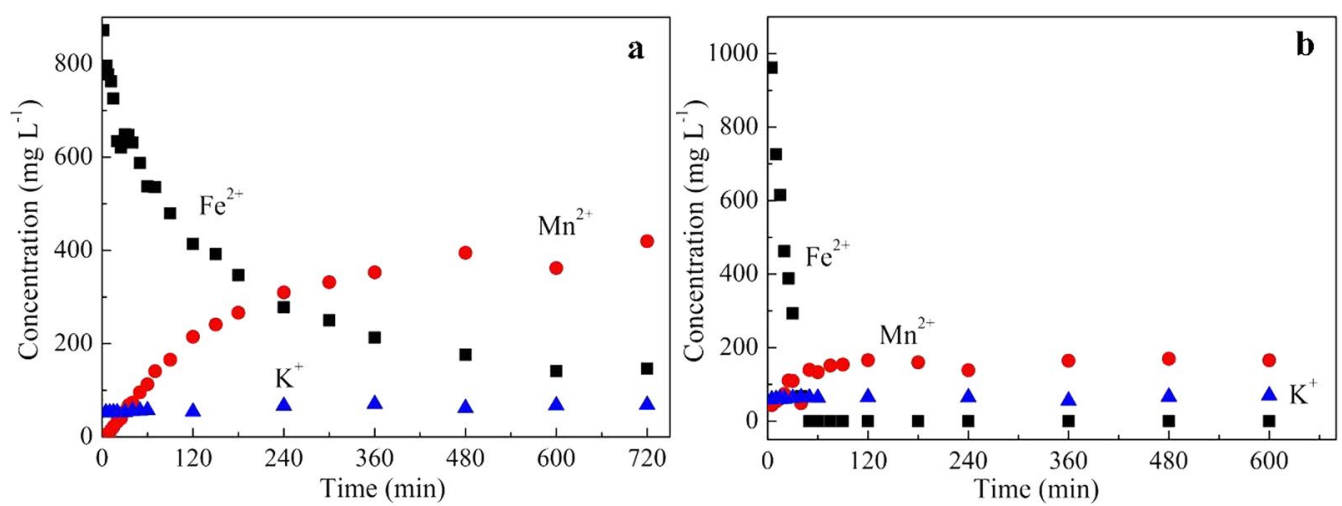

Fig. 5 The concentration of $\mathrm{Fe}^{2+}, \mathrm{Mn}^{2+}$ and $\mathrm{K}^{+}$in reaction system of $20 \mathrm{mM} \mathrm{Fe}^{2+}$ oxidized by $1.0 \mathrm{~g} \mathrm{~L}^{-1}$ birnessite with $\mathrm{pH} 5.5$ in nitrogen atmosphere $(\mathbf{a})$ and in air $(\mathbf{b})$ at different times

respectively, at $720 \mathrm{~min}$. Organic matter, silicate, phosphate, and metal ions also participate in the formation of ferric oxides and exhibit different effects on transformation rate $[31,32,37]$. The presence of $\mathrm{Fe}^{2+}$ and $\mathrm{Mn}^{2+}$ might participate in the transformation of ferric oxides including lepidocrocite and goethite. $\mathrm{Fe}^{2+}$ works as electron mediators and accelerate the formation of goethite, however, the other metal ions, such as $\mathrm{Ti}^{4+}$, $\mathrm{Cu}^{2+}$ and $\mathrm{Cr}^{3+}$, effectively interfere with the transformation for the interruption of electron transfer [10,31]. In order to study the influence of $\mathrm{Fe}^{2+}$ and $\mathrm{Mn}^{2+}$ on the transformation of ferric oxides, $\mathrm{Fe}^{2+}$ and $\mathrm{Mn}^{2+}$ were added to $\mathrm{Fe}_{2}\left(\mathrm{SO}_{4}\right)_{3}$ solution with $\mathrm{pH} 5.5$ and solid products were analyzed.

Figure 6 shows the XRD patterns of solid products of $\mathrm{Fe}_{2}\left(\mathrm{SO}_{4}\right)_{3}\left(10 \mathrm{mmol} \mathrm{L}{ }^{-1}\right), \mathrm{Fe}_{2}\left(\mathrm{SO}_{4}\right)_{3}\left(10 \mathrm{mmol} \mathrm{L}{ }^{-1}\right) /$ $\mathrm{MnSO}_{4}\left(10 \mathrm{mmol} \mathrm{L}^{-1}\right)$, and $\mathrm{Fe}_{2}\left(\mathrm{SO}_{4}\right)_{3}\left(10 \mathrm{mmol} \mathrm{L}^{-1}\right) /$ $\mathrm{FeSO}_{4}\left(10 \mathrm{mmol} \mathrm{L}^{-1}\right)$ aqueous solutions in nitrogen atmosphere with $\mathrm{pH} 5.5$ at different times. As for $\mathrm{Fe}_{2}\left(\mathrm{SO}_{4}\right)_{3}$ aqueous solution, amorphous ferric (hydr) oxide was formed at $\mathrm{pH} 5.5$, and its crystallinity did not obviously increase after 25 days. The addition of $\mathrm{Mn}^{2+}$ facilitated the formation of a mixture of lepidocrocite and goethite, and the latter was major product after 25 days (Fig. 6b). The presence of $\mathrm{Fe}^{2+}$ significantly accelerated the formation of lepidocrocite and goethite, which were observed after 1 days (Fig. 6c). Lepidocrocite was the major product in the initial stage, and would slowly transform into goethite, which was indicated by the relative change in the intensity of XRD peaks. These results exhibited that $\mathrm{Fe}^{2+}$ had higher catalytic activity than $\mathrm{Mn}^{2+}$ for the formation of crystalline ferric oxides, and further suggested that not all transition metal ions inhibited the formation of goethite from lepidocrocite, which was likely due to the particular affinity and constant $\mathrm{pH}$ during this reaction process $[2,31,38]$.

\section{The oxidation of $\mathrm{Fe}^{2+}$ by birnessite in air}

In soils and sediments, redox reactions are usually driven by oxygen, ferric irons, manganese oxides and microorganisms $[8,39,40]$. To simulate the abiotic oxidation behavior of $\mathrm{Fe}^{2+}$ by birnessite in an open system, air was admitted into the reaction system, and intermediate products were characterized. As shown in Fig. 7, a mixture of birnessite and lepidocrocite was produced within 6 days, and then goethite was formed after 10 days. The fact that the participation of oxygen improved the chemical stability of birnessite was further verified by the concentration of released $\mathrm{Mn}^{2+}$ as shown in Fig. 5b. The remove rate of $\mathrm{Fe}^{2+}$ concentration significantly increased, compared with the reaction under anoxic condition, and $\mathrm{Fe}^{2+}$ concentration decreased to about zero at $1 \mathrm{~h}$ (Fig. 5). However, the concentration of generated $\mathrm{Mn}^{2+}$ and $\mathrm{K}^{+}$just reached about 170 and $70 \mathrm{mg} \mathrm{L}^{-1}$ after $6 \mathrm{~h}$, respectively. These results indicated the oxidation of $\mathrm{Fe}^{2+}$ by oxygen and the improvement of the chemical stability of birnessite. The chemical stability of birnessite was improved in the presence of oxygen, likely due to the fact that the newly formed $\mathrm{Mn}(\mathrm{III})$ from $\mathrm{Mn}(\mathrm{IV})$ in birnessite would be re-oxidized by oxygen in air $[28,30,34,39,41]$. In our previous work, during the oxidation process of soluble sulfide by todorokite and oxygen, the reaction rate was controlled by the rate of diffusion of soluble sulfide and todorokite, and the admission of oxygen reduced the initial oxidation rate of soluble sulfide by todorokite due to the decrease of active $\mathrm{Mn}(\mathrm{III})$ content in manganese oxide owing to the oxidation of $\mathrm{Mn}$ (III) to $\mathrm{Mn}$ (IV) by oxygen [28]. On the other hand, oxygen would directly oxidize ferrous ions, and the consumption of oxidant birnessite decreased in the same reaction system. The improved redox stability of birnessite was further confirmed by TEM image as shown in Fig. 4d. Although 

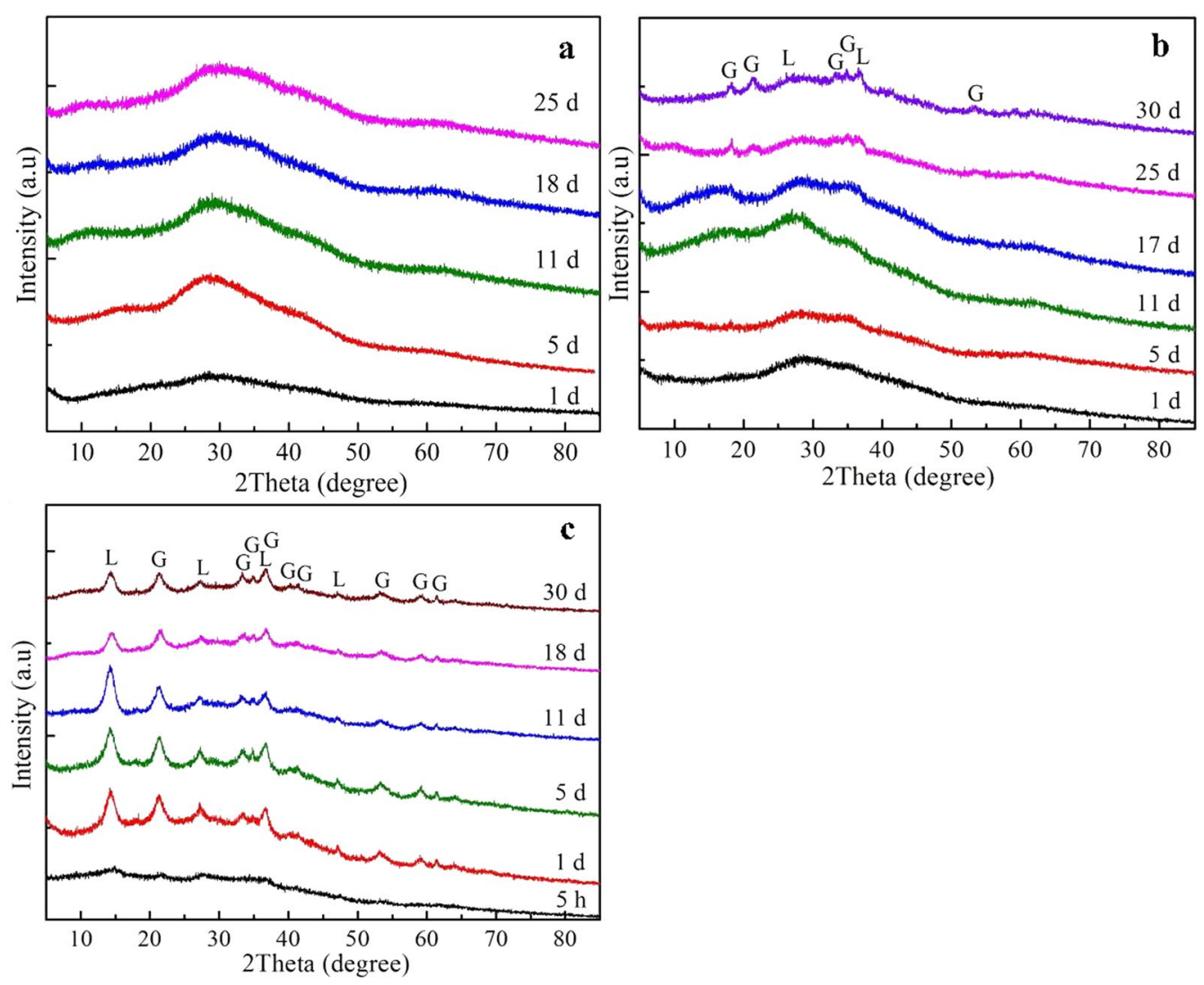

Fig. 6 XRD patterns of solid products of $10 \mathrm{mM} \mathrm{Fe} 2\left(\mathrm{SO}_{4}\right)_{3}(\mathbf{a}), \mathrm{Fe}_{2}\left(\mathrm{SO}_{4}\right)_{3}(10 \mathrm{mM}) / \mathrm{MnSO}_{4}(10 \mathrm{mM})(\mathbf{b}), \mathrm{and} \mathrm{Fe}_{2}\left(\mathrm{SO}_{4}\right)_{3}(10 \mathrm{mM}) / \mathrm{FeSO}_{4}(10 \mathrm{mM})(\mathbf{c})$ aqueous solutions in nitrogen atmosphere with $\mathrm{pH} 5.5$ at different times
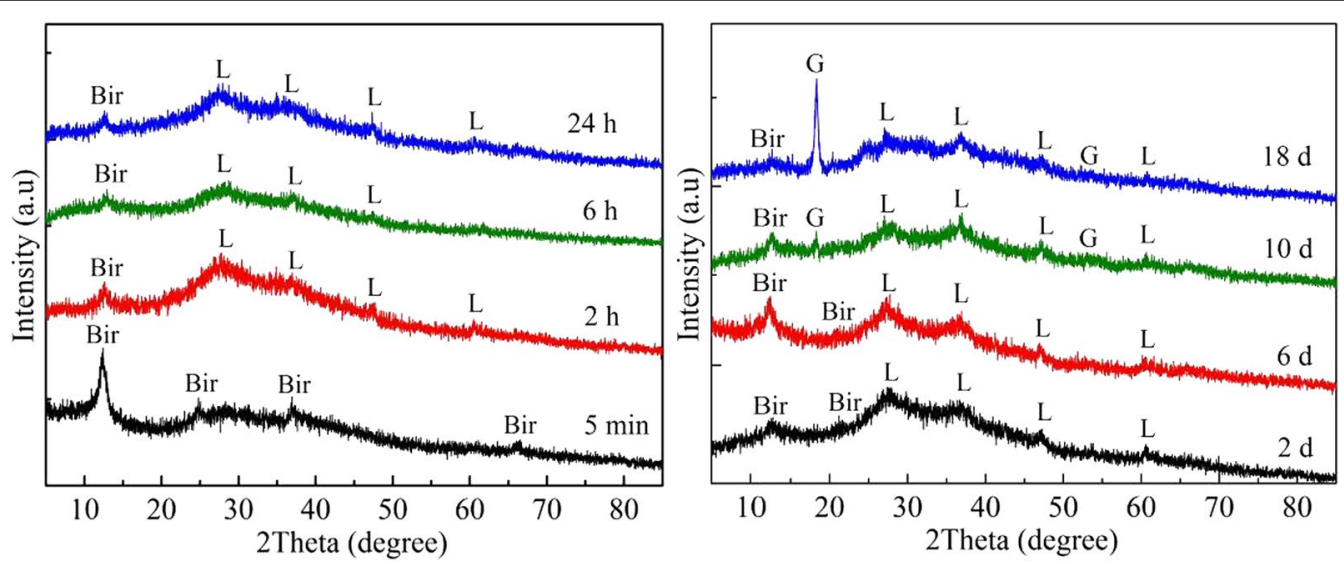

Fig. 7 XRD patterns of solid products of $20 \mathrm{mM} \mathrm{Fe}^{2+}$ oxidized by $1.0 \mathrm{~g} \mathrm{~L}^{-1}$ birnessite in air at different times

the morphologies of birnessite became pulverized and indistinct, the aggregates could be observed. These particles were completely dissolved and unobservable as the redox reaction occurred in nitrogen atmosphere for the same time (Fig. 4c). There was no obvious change for the concentration of released $\mathrm{K}^{+}$likely due to ion-exchange by $\mathrm{Fe}^{3+/ 2+}$ and $\mathrm{H}^{+}$during the initial stage and the complete reduction and dissolve during the final stages.

In order to further investigate the influence of oxygen on the transformation process of ferrous ions to ferric oxides, air was directly pumped into aqueous solution containing $\mathrm{FeSO}_{4}$ of $20 \mathrm{mmol} \mathrm{L}^{-1}$ at $\mathrm{pH}$ of 5.5 and 7.0, 
respectively. Figure 8 shows the XRD patterns of solid products at different times. Amorphous ferric oxide was first formed and then transformed into a mixture of lepidocrocite and goethite with low degree of crystallinity when reaction system was controlled at $\mathrm{pH} 5.5$. When $\mathrm{pH}$ was adjusted to 7.0, crystalline lepidocrocite was formed with a small amount of weak crystalline goethite after $1 \mathrm{~h}$. The relative content of lepidocrocite and goethite had no significant changes after 7 days. In this work, $\mathrm{pH}$ played an important role in the transformation of ferric oxides. The formation of $\mathrm{FeOH}^{+}$accelerated the dissolution of amorphous ferric oxide at $\mathrm{pH}$ 7.0, which facilitated the transformation of lepidocrocite during the dissolution/reprecipitation process induced by $\mathrm{Fe}^{2+}$ $[3,38]$. As pH was less than 5.0, single-phased goethite could be formed in this system (figure not shown), which further indicated the transformation process from lepidocrocite to goethite.

The morphologies of the solid products were characterized by TEM as shown in Fig. 9. Needle-like goethite and amorphous particles within $100 \mathrm{~nm}$ were formed when aqueous $\mathrm{FeSO}_{4}$ oxidized by air at $\mathrm{pH} 5.5$ for $7 \mathrm{~d}$. As $\mathrm{pH}$ increased to 7.0, homogeneous platelet particles of lepidocrocite were formed with particle size more than $200 \mathrm{~nm}$. These results are consistent with the XRD identification (Fig. 8), further indicated the influence of oxygen in air on the oxidation rate of $\mathrm{Fe}^{2+}$ and the reciprocal transformation of ferric oxides, such as goethite and lepidocrocite.

\section{The oxidation kinetics of $\mathrm{Fe}^{2+}$ by birnessite}

The influential factors on the reaction rate of ferrous ions oxidation by birnessite were considered including $\mathrm{Fe}^{2+}$ concentration, $\mathrm{pH}$, temperature, and oxygen in air. As shown in Fig. 10a, when $\mathrm{Fe}^{2+}$ ion concentration was controlled at 10,20 , and $40 \mathrm{mmol} \mathrm{L}^{-1}$, after $12 \mathrm{~h}$ of reaction, the concentration of consumed $\mathrm{Fe}^{2+}$ reached about 559, 705 , and $990 \mathrm{mg} \mathrm{L}^{-1}$, which corresponding consumption rates approaching to 100,87 and $61 \%$, respectively. The amount of released $\mathrm{Mn}^{2+}$ can be used to indicate the redox rate $[18,20,21,42]$. In this work, higher concentration of reactant facilitated the larger capacity for $\mathrm{Fe}^{2+}$ oxidation. $\mathrm{Mn}(\mathrm{III})$ complexes would not be formed, and dissolved $\mathrm{Mn}^{2+}$ ions and ferric (hydr)oxides including goethite and lepidocrocite were major products [20, 42]. The redox reaction may be represented as follows:

$$
\begin{aligned}
& \mathrm{K}_{0.23} \mathrm{MnO}_{2.03} \cdot 0.6 \mathrm{H}_{2} \mathrm{O}+1.83 \mathrm{Fe}^{2+}+1.03 \mathrm{H}_{2} \mathrm{O} \rightarrow \mathrm{Mn}^{2+} \\
& +1.83 \mathrm{FeOOH}+0.23 \mathrm{~K}^{+}+1.43 \mathrm{H}^{+}
\end{aligned}
$$

As reported, the generation of $\mathrm{FeOOH}$ could not be confirmed by XRD [20], however, the transformation process of ferric (hydr)oxides was characterized and illustrated in this work. According to reaction (1), the molar ratio of the concentration of oxidized $\mathrm{Fe}^{2+}$ to that of the released $\mathrm{Mn}^{2+}$ would be 1.83 (mass ratio: 1.86). In this experiment, the removal $\mathrm{Fe}^{2+}$ in reaction solution was all treated as the oxidized Fe(III), which existed as adsorption states on the surface of manganese oxides and the precipitate of ferric (hydr)oxides including goethite and lepidocrocite. The interrelation of the concentration of oxidized $\mathrm{Fe}^{2+}$ and the released $\mathrm{Mn}^{2+}$ was compared and the influence of reaction conditions was studied.

Figure 10b shows the concentration of released $\mathrm{Mn}^{2+}$ as the reaction proceeded. In the initial stage, the release rate of $\mathrm{Mn}^{2+}$ was similar when $\mathrm{Fe}^{2+}$ of 10 and $20 \mathrm{mmol} \mathrm{L}^{-1}$ was oxidized by birnessite of $1.0 \mathrm{~g} \mathrm{~L}^{-1}$, and it significantly increased when $\mathrm{Fe}^{2+}$ of $40 \mathrm{mmol} \mathrm{L}^{-1}$ was used instead. The concentration of released $\mathrm{Mn}^{2+}$ could reach 208, 420, and $463 \mathrm{mg} \mathrm{L}^{-1}$, respectively, after reaction of $12 \mathrm{~h}$. The amount of the released $\mathrm{Mn}^{2+}$ increased with an increase in the concentration of ferrous ions,
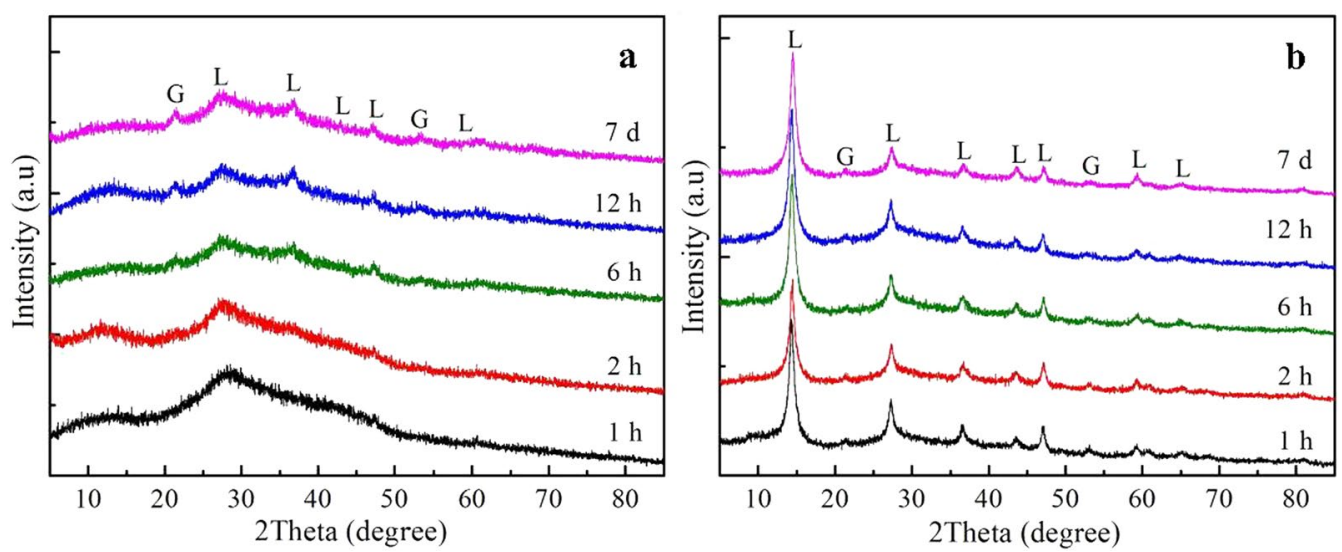

Fig. 8 XRD patterns of solid products of $20 \mathrm{mM} \mathrm{FeSO}_{4}$ oxidized by air with $\mathrm{pH} 5.5$ (a) and pH 7.0 (b) at different times 


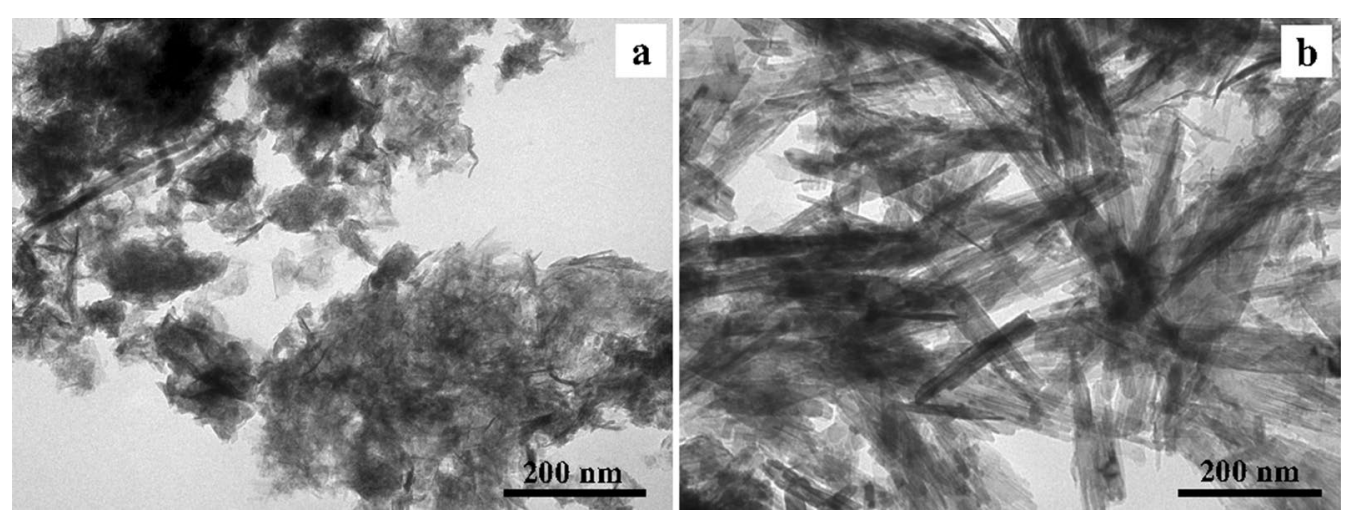

Fig. 9 TEM images of solid product of $20 \mathrm{mM} \mathrm{FeSO}_{4}$ oxidized by air at pH 5.5 (a) and pH 7.0 (b) for 7 days
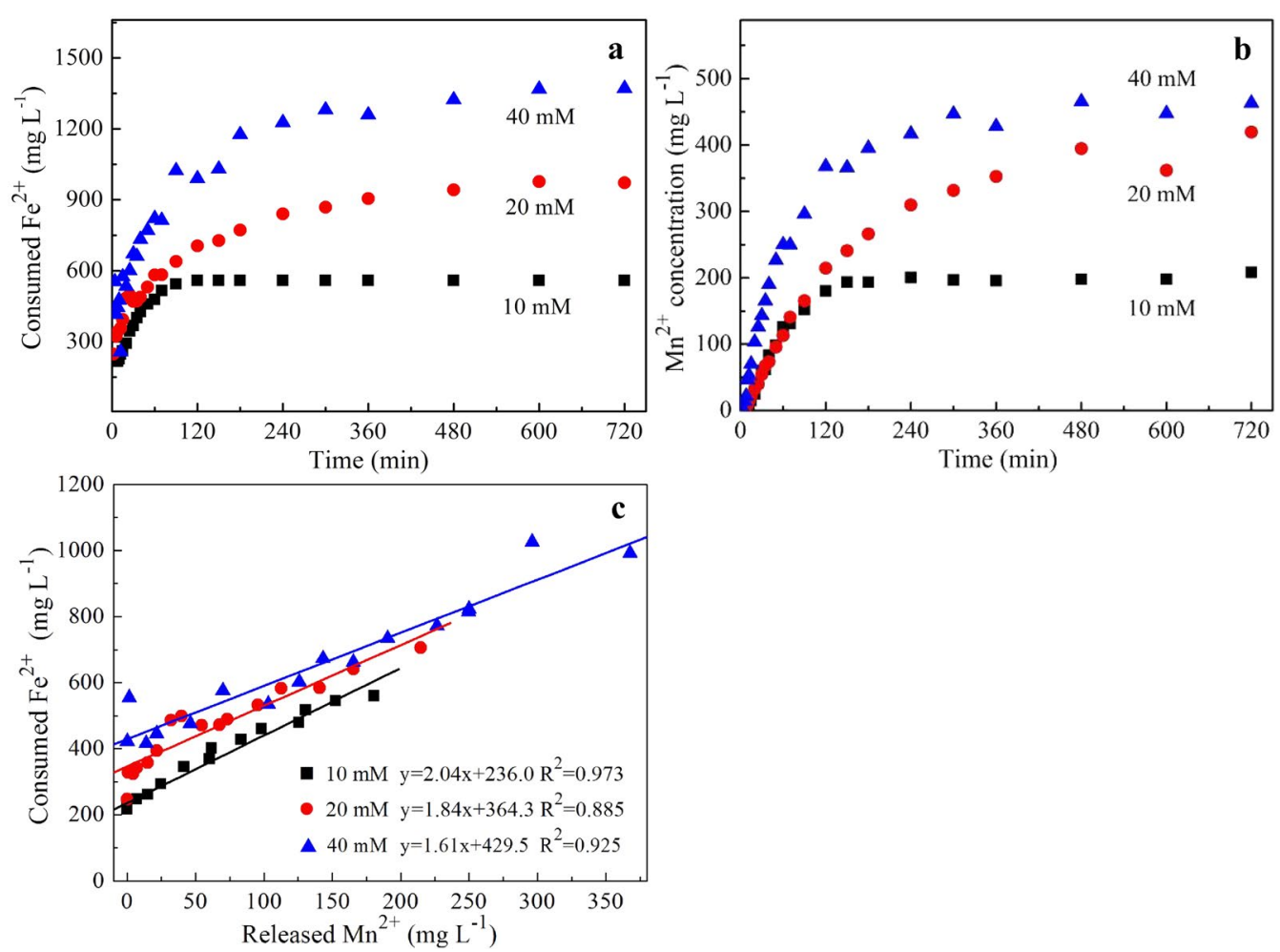

Fig. 10 Concentration of consumed Fe ${ }^{2+}$ with different initial concentration (a) and released $\mathrm{Mn}^{2+}$ concentration (b) and the relationship of consumed $\mathrm{Fe}^{2+}$ and released $\mathrm{Mn}^{2+}$ concentration in reaction system within $120 \mathrm{~min}(\mathbf{c})$

suggesting that high concentration of $\mathrm{Fe}^{2+}$ accelerated the reduction of birnessite. The mass ratios of $\mathrm{Fe}^{2+}$ consumption to $\mathrm{Mn}^{2+}$ production ( $\Delta \mathrm{Fe} / \Delta \mathrm{Mn}$ slopes) were $2.04,1.84$, and 1.61 when ferrous ion concentration was controlled at 10,20 , and $40 \mathrm{mmol} \mathrm{L}^{-1}$, respectively (Fig. 10c).

During the reduction process of birnessite, active adsorption sites would first be quickly occupied by $\mathrm{Fe}^{2+}$, and then redox reactions occurred. Subsequently, the newly formed $\mathrm{Mn}^{2+}$ from the reduction of birnessite would be paritially released into aqueous system, because some $\mathrm{Mn}^{2+}$ ions would be readsorbed on the surface of newly exposed birnessite if incomplete redox occurred. We have compared the theoretical and experimental concentrations of consumed $\mathrm{Fe}^{2+}$ and released $\mathrm{Mn}^{2+}$ for the reactions of $\mathrm{Fe}^{2+}$ of 10,20 and $40 \mathrm{mmol} \mathrm{L}^{-1}$ and birnessite of $1 \mathrm{~g} \mathrm{~L}^{-1}$, respectively. When $\mathrm{Fe}^{2+}$ of $10 \mathrm{mmol} \mathrm{L}^{-1}$ participated in the reaction, $5.46 \mathrm{mmol} \mathrm{L}^{-1}$ 
$\mathrm{Mn}^{2+}$ should be released for the complete oxidation of $\mathrm{Fe}^{2+}$ by excessive birnessite. When $\mathrm{Fe}^{2+}$ concentrations were 20 and $40 \mathrm{mmol} \mathrm{L}^{-1}$, excessive $\mathrm{Fe}^{2+}$ was used and about $9.32 \mathrm{mmol} \mathrm{L}^{-1} \mathrm{Mn}^{2+}$ should be released. However, the concentration of released $\mathrm{Mn}^{2+}$ was determined to be 3.58, 6.03 and $8.12 \mathrm{mmol} \mathrm{L}^{-1}$ after $30 \mathrm{~min}$ for the reactions of birnessite of $1 \mathrm{~g} \mathrm{~L}^{-1}$ and $\mathrm{Fe}^{2+}$ of 10 , 20 and $40 \mathrm{mmol} \mathrm{L}^{-1}$, respectively. All the released $\mathrm{Mn}^{2+}$ concentrations were lower than the theoretical values. Therefore, all the reductions of birnessite by $\mathrm{Fe}^{2+}$ were incomplete when $\mathrm{Fe}^{2+}$ ions were controlled at 10, 20 and $40 \mathrm{mmol} \mathrm{L}^{-1}$, and the formation of the precipitate of ferric (hydr)oxides including goethite and lepidocrocite possibly inhibited the further reduction of birnessite $[20,22,23,43]$. Another possibility should be considered for the low concentration of released $\mathrm{Mn}^{2+}$, the formed $\mathrm{Mn}^{2+}$ would be partially readsorbed on the surface of newly exposed birnessites, resulting in a decrease in released $\mathrm{Mn}^{2+}$ concentration. The similar concentrations of released $\mathrm{Mn}^{2+}$ were determined as $\mathrm{Fe}^{2+}$ concentration was controlled at 10 and $20 \mathrm{mmol} \mathrm{L}^{-1}$, suggesting that $\mathrm{Mn}^{2+}$ could be readsorbed because new active adsorption sites would be exposed with the partial reduction and dissolution of birnessite.

As shown in Fig. 5, released $\mathrm{K}^{+}$was determined to be $1.34 \mathrm{mmol} \mathrm{L}^{-1}$ within $5 \mathrm{~min}$, and $\mathrm{K}^{+}$concentrations increased to 1.46 and $1.79 \mathrm{mmol} \mathrm{L}^{-1}$ after reaction of 60 and $360 \mathrm{~min}$, respectively. However, complete reduction of birnessite would result in the concentration of released $\mathrm{K}^{+}$about $2.15 \mathrm{mmol} \mathrm{L}^{-1}$, which further suggested that rapid adsorption in the initial stage and the incomplete reduction of birnessite occurred in this process.

Figure 10a shows the concentration of $\mathrm{Fe}^{2+}$ at different times as the initial concentrations of $\mathrm{Fe}^{2+}$ were changed from 10 to $40 \mathrm{mmol} \mathrm{L}^{-1}$ in reaction systems. The consumed $\mathrm{Fe}^{2+}$ concentration reached 4.0, 4.4 and $7.5 \mathrm{mmol} \mathrm{L}^{-1}$ within $2 \mathrm{~min}$, and they approached to 6.6 , 8.4 and $12.0 \mathrm{mmol} \mathrm{L}^{-1}$ after $30 \mathrm{~min}$, respectively. However, the concentrations of released $\mathrm{Mn}^{2+}$ were almost zero within $2 \mathrm{~min}$, and they approached to 1.1, 1.0 and $2.6 \mathrm{mmol} \mathrm{L}^{-1}$ when $\mathrm{Fe}^{2+}$ of 10,20 , and $40 \mathrm{mmol} \mathrm{L}^{-1}$ participated in the reaction, respectively. These results further indicated that the adsorption of $\mathrm{Fe}^{2+}$ on birnessite surface might be the major reaction, and high concentration of $\mathrm{Fe}^{2+}$ facilitated the reduction of birnessite and the corresponding release rate of $\mathrm{Mn}^{2+}$, which proved the redox kinetics of birnessite and ferrous ions [20,22].

As reported, for the oxidation of $\mathrm{Fe}^{2+}$ and $\mathrm{Cr}^{3+}$ by manganese oxides, reaction rate was controlled by chemical reaction and not dependent upon diffusion from the bulk solution or transport of dissolved species from birnessite at $\mathrm{pH}>4$, and initial reduction rates can be significantly faster than long-term rates because of the inhibition by $\mathrm{Fe}(\mathrm{III})$ precipitates [20, 22, 23, 43]. In this work, the adsorption of $\mathrm{Fe}^{2+}$ on the surface of birnessite was extremely fast, and it could be proved by the release rate and concentration variation of $\mathrm{K}^{+}$. In the initial stage, almost the similar amount of $\mathrm{Fe}^{2+}$ would be quickly adsorbed on the surface of birnessite although the different concentrations of $\mathrm{Fe}^{2+}$ were applied because of the fixed concentration of oxidant birnessite. Therefore, the adsorption of $\mathrm{Fe}^{2+}$ played an important role in the decrease of $\mathrm{Fe}^{2+}$ in the initial stage, and they have the similar concentration changing trend due to the same amount of birnessite. The decrease in $\mathrm{Fe}^{2+}$ concentration was mainly attributed to the adsorption reaction in the initial stage. The incomplete redox reactions occurred, and redox reaction worked as the rate-determining step. The redox rate and the corresponding release rate of $\mathrm{Mn}^{2+}$ increased with an increase in the concentration of $\mathrm{Fe}^{2+}$ [20]. The change amplitude of the concentration of $\mathrm{Fe}^{2+}$ was not as significant as that of $\mathrm{Mn}^{2+}$. Therefore, the decrease of $\Delta \mathrm{Fe} / \Delta \mathrm{Mn}$ values with an increase in $\mathrm{Fe}^{2+}$ concentration was owing to the increase redox rate as $\mathrm{Fe}^{2+}$ concentration increased.

The influence of $\mathrm{pH}$, temperature, and air on the release rate of $\mathrm{Mn}^{2+}$ was further studied in the oxidation process of $\mathrm{Fe}^{2+}$ of $20 \mathrm{mmol} \mathrm{L}^{-1}$ by birnessite of $1.0 \mathrm{~g} \mathrm{~L}^{-1}$. As shown in Fig. $11 \mathrm{a}, \mathrm{Mn}^{2+}$ release rate increased with an increase of $\mathrm{pH}$ in reaction system, suggesting redox rate increasing with an increase in $\mathrm{OH}^{-}$concentration. High $\mathrm{pH}$ might also decrease the solubility of $\mathrm{Mn}^{2+}$. Therefore, the dissolving rate is not controlled by the transport of reduced species away from the surface, that is to say, $\mathrm{Mn}^{2+}$ release into solution is not the rate-determining step [42], which agreed with the results and analysis for the reaction systems with $\mathrm{Fe}^{2+}$ of different concentrations. Usually, the oxidation activity of manganese oxide is enhanced with increasing $\mathrm{H}^{+}$concentration $[41,42]$. However, increasing $\mathrm{pH}$ enriched surface negative charge amount, consequently the adsorption capacity increased $[44,45])$, and high $\mathrm{pH}$ thermodynamically accelerated redox reaction of $\mathrm{Fe}^{2+}$ and manganese oxides [20, 23].

Reaction rate increased with an increase in temperature (Fig. 11b), suggesting a corresponding increase in oxidation activity of birnessite [20]. Another possibility might be attributed to the increase of adsorption capacity as reaction temperature increased. Enhancement of adsorption capacity of birnessite at higher temperatures may be ascribed to the enlargement of pore size and/ or activation of the adsorbent surface (Han et al., 2006). When air was bubbled into the aqueous system, compared with the reaction under anoxic condition, reaction rate was increased (Fig. 11a, c) due to the participation of oxygen. The amount of released $\mathrm{Mn}^{2+}$ increased within $12 \mathrm{~h}$ because of the incomplete redox as shown in Fig. 2. 

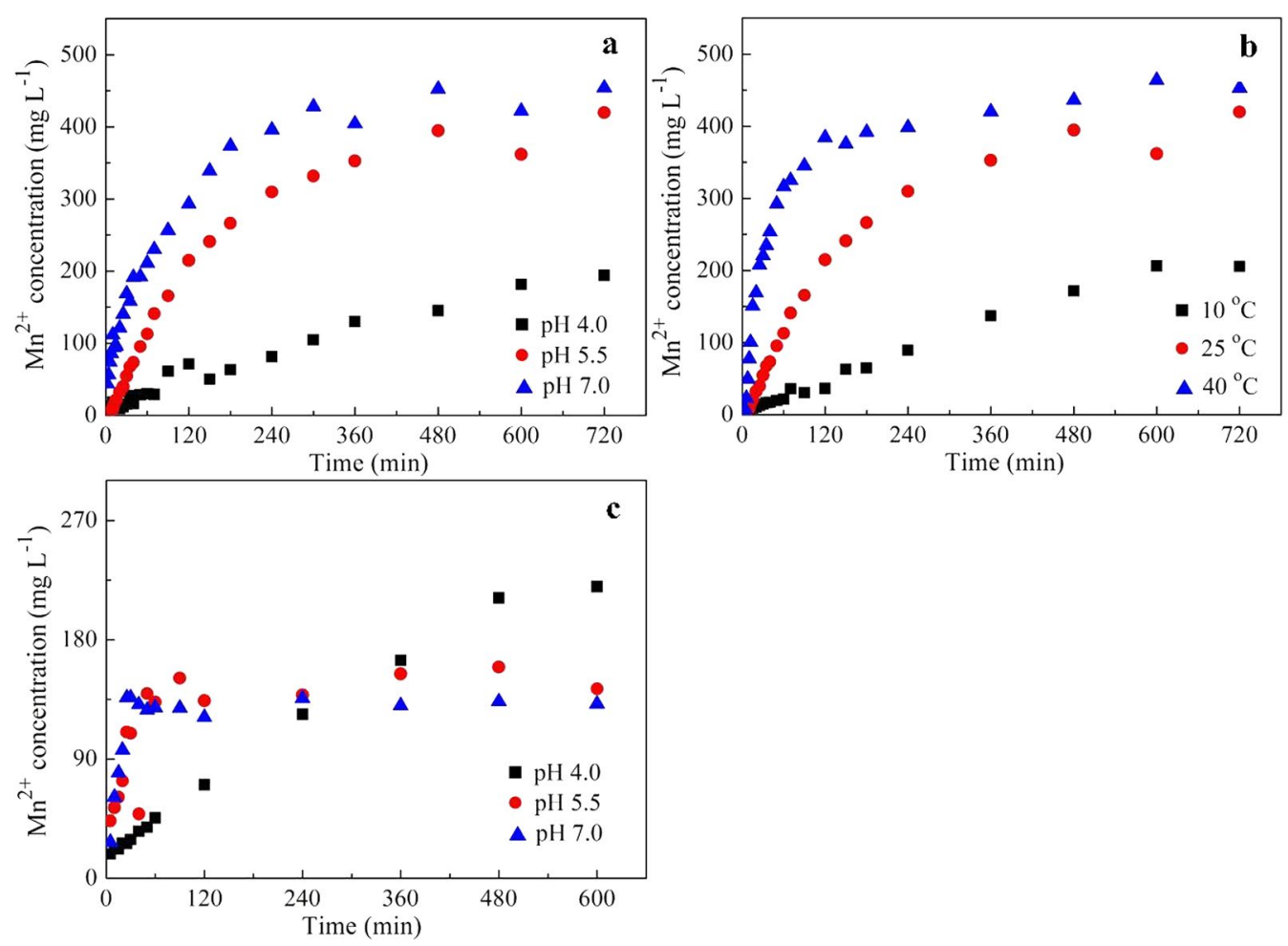

Fig. 11 The concentration of released $\mathrm{Mn}^{2+}$ in reaction process of $20 \mathrm{mM} \mathrm{Fe}^{2+}$ and $1.0 \mathrm{~g} \mathrm{~L}^{-1}$ birnessite under different conditions: a $\mathrm{pH}$ 4.0-7.0, $25^{\circ} \mathrm{C}, \mathrm{N}_{2} ; \mathbf{b} \mathrm{pH} 5.5,10-40^{\circ} \mathrm{C}, \mathrm{N}_{2} ; \mathbf{c} \mathrm{pH} 4.0-7.0,25^{\circ} \mathrm{C}$, air

It was also noted that the release rate of $\mathrm{Mn}^{2+}$ increased with increasing $\mathrm{pH}$ within $4 \mathrm{~h}$, and then it would keep increasing and stable when $\mathrm{pH}$ values were controlled at 4.0, 5.5 and 7.0, respectively (Fig. 11c). The redox reaction between birnessite and ferrous ions might be intensified in the late stage likely owing to the higher oxidation activity of birnessite at lower $\mathrm{pH}$. These results further indicated that the presence of oxygen facilitated the chemical stability of birnessite in the initial stage, because Mn(II/ III) would be oxidized to Mn(IV) oxide in air atmosphere (Schippers et al., 2005; [28, 41].

The redox rate was further analyzed and confirmed by comparing the relationship of consumed $\mathrm{Fe}^{2+}$ and released $\mathrm{Mn}^{2+}$ concentration in the initial stage. As discussed above, $\Delta \mathrm{Fe} / \Delta \mathrm{Mn}$ slope demonstrates the chemical stability and oxidation capacity of birnessite. From Eq. (1), $\Delta \mathrm{Fe} / \Delta \mathrm{Mn}$ slope of about 1.86 (mass ratio) suggested the balance of adsorption/oxidation of $\mathrm{Fe}^{2+}$ and the reduction/release of $\mathrm{Mn}^{2+}$, and higher slope of $\Delta \mathrm{Fe} /$ $\Delta \mathrm{Mn}$ indicates higher adsorption/oxidation rate of $\mathrm{Fe}^{2+}$ and higher chemical stability of birnessite. As shown in Fig. 12, this slope increased with an increase in $\mathrm{pH}$ and a decrease of temperature. These results further revealed that properly increasing alkalinity favored the adsorption and oxidation of $\mathrm{Fe}^{2+}$ on the surface of birnessite, resulting in the increase of the release $\mathrm{Mn}^{2+}$ concentration. Therefore, $\Delta \mathrm{Fe} / \Delta \mathrm{Mn}$ slope decreased with an increase in $\mathrm{pH}$ of reaction system. The lowest slope of 1.70 and the greatest slope of 5.69 were obtained at 10 and $40{ }^{\circ} \mathrm{C}$, respectively. High temperature and proper high $\mathrm{pH}$ accelerated the redox reaction and corresponding $\mathrm{Mn}^{2+}$ dissolving, and adsorption might be the major reaction at lower temperature.

It was noted that this slope significantly increased from $2.95,1.84$, and 1.77 to $19.43,8.86$, and 6.02 in the presence of air when $\mathrm{pH}$ was controlled at 4.0, 5.5, and 7.0, respectively (Fig. 12c). These results indicated the rapid oxidation/adsorption of $\mathrm{Fe}^{2+}$ and slow reduction/dissolution of birnessite. Other characterization results indicated that the decrease rate of $\mathrm{Fe}^{2+}$ concentration significantly improved (Fig. 5b), and birnessite could be determined after 18 days (Figs. 7b, 4d), and the concentration of released $\mathrm{Mn}^{2+}$ dramatically decreased after bubbling air. High $\mathrm{pH}$ accelerated the oxidation of $\mathrm{Fe}^{2+}$ by birnessite through surface adsorption, and improved the chemical stability, and these factors affected the redox rate at the same time. Combining with these results, it could be safely concluded that the presence of air (oxygen) facilitated the fast oxidation of $\mathrm{Fe}^{2+}$ and the improvement of chemical stability of birnessite. These 

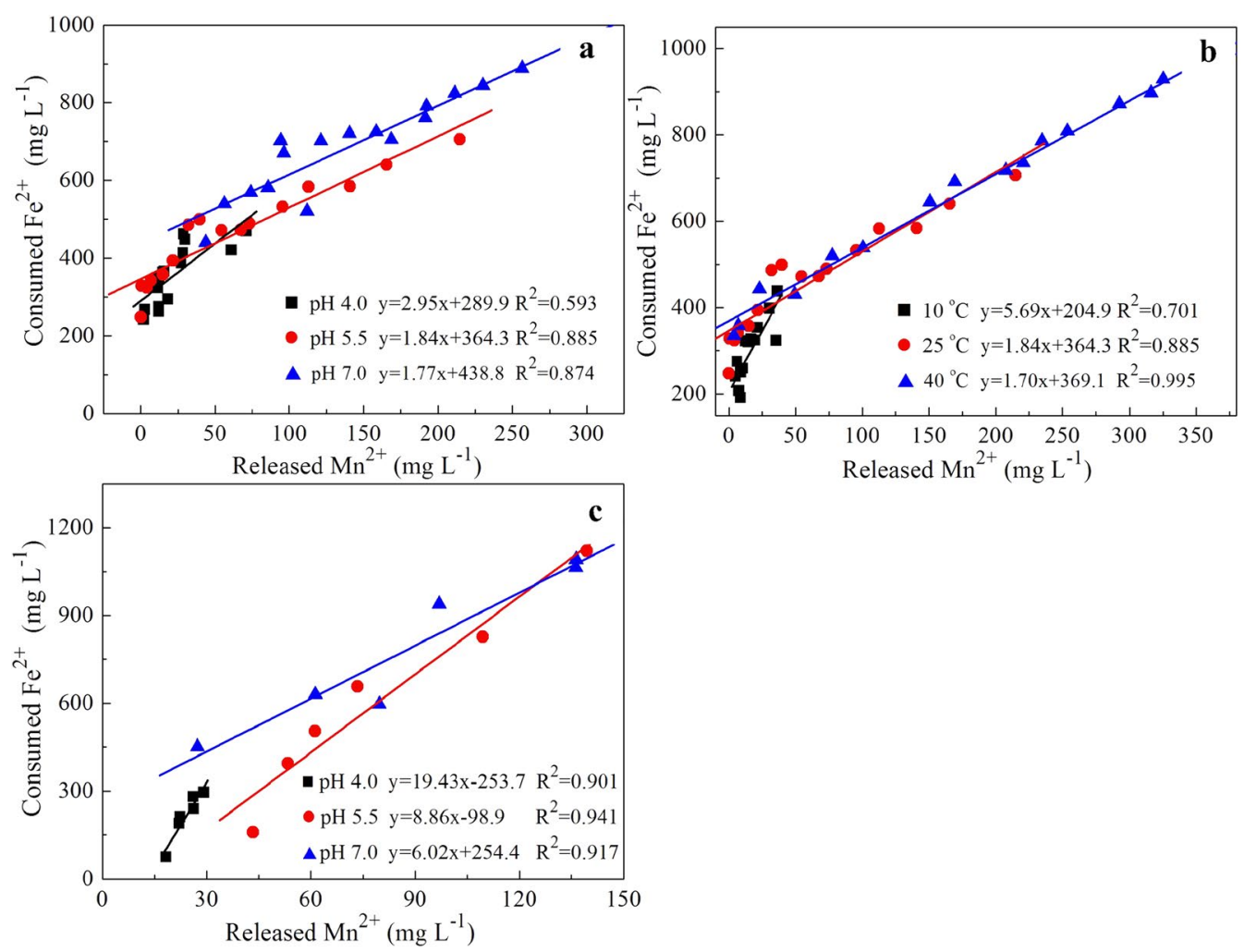

Fig. 12 The relationship of consumed $\mathrm{Fe}^{2+}$ and released $\mathrm{Mn}^{2+}$ concentration in the initial reaction stage of $20 \mathrm{mM} \mathrm{Fe}^{2+}$ and $1.0 \mathrm{~g} \mathrm{~L}^{-1}$ birnessite under different conditions: a pH $4.0-7.0,25^{\circ} \mathrm{C}, \mathrm{N}_{2} ; \mathbf{b ~ p H} 5.5,10-40^{\circ} \mathrm{C}, \mathrm{N}_{2} ; \mathbf{c} \mathrm{pH} 4.0-7.0,25^{\circ} \mathrm{C}$, air

results about the relationship between the oxidized $\mathrm{Fe}^{2+}$ and released $\mathrm{Mn}^{2+}$ concentration were consistent with the change trend of released $\mathrm{Mn}^{2+}$ concentration during the reaction process. Temperature, $\mathrm{pH}$, and oxygen significantly affected the adsorption and oxidation rate with different reaction mechanism.

\section{Conclusions}

The stimulated redox behaviors of ferrous ions and birnessite were studied, and the influence of $\mathrm{Fe}^{3+}, \mathrm{Mn}^{2+}$, temperature, and the presence of air on the transformation process of ferric oxides was investigated with $\mathrm{pH}$ 4-7. A mixture of goethite and lepidocrocite was formed with the redox reaction of ferrous ion and birnessite, and lepidocrocite transformed into goethite at the final stage. The transformation from amorphous ferric (hydr)oxide to lepidocrocite and goethite was accelerated by adding $\mathrm{Fe}^{2+}$ and $\mathrm{Mn}^{2+}$ into $\mathrm{Fe}_{2}\left(\mathrm{SO}_{4}\right)_{3}$ aqueous solution at $\mathrm{pH}$ 5.5 , and $\mathrm{Fe}^{2+}$ showed better catalytic activity compared with $\mathrm{Mn}^{2+}$. A mixed phase of goethite and lepidocrocite was formed within a day. The presence of air (oxygen) improved the chemical stability of birnessite, and significantly accelerated the oxidation rate of ferrous ions. In the oxidation reaction of ferrous ions by oxygen in air, low and high $\mathrm{pH}$ values facilitated the formation of goethite and lepidocrocite, respectively. Amorphous ferric (hydr)oxide was formed during the initial stage, and a mixture of poorly crystallized goethite and lepidocrocite was formed after 7 days when $\mathrm{pH}$ was controlled at 5.5. A mixture of lepidocrocite and goethite was formed, and the latter was the main product with high crystallinity at $\mathrm{pH}$ 7.0. The redox rate was indicated by the disappearing rate of $\mathrm{Fe}^{2+}$ and the appearing rate of $\mathrm{Mn}^{2+}$ in reaction system. The oxidation rate increased with an increase in the initial concentration of $\mathrm{Fe}^{2+}, \mathrm{pH}$, and temperature, and the rate was controlled by the redox reaction of adsorbed $\mathrm{Fe}^{2+}$ with birnessite, and accelerated in the presence of air.

\section{Authors' contributions}

TYG carried out redox experiments and SEM analysis, ZHJ and YGS conducted FTIR, TEM, and ion chromatography measurements and analysis. FL, YSZ, XHF, and CFC helped with the analysis of results. GHQ had the idea for the project. All authors read and approved the manuscript.

\section{Author details}

${ }^{1}$ Key Laboratory of Arable Land Conservation (Middle and Lower Reaches of Yangtse River), Ministry of Agriculture, College of Resources and Environment, Huazhong Agricultural University, Wuhan 430070, People's Republic of China. ${ }^{2}$ Department of Chemistry, University of Connecticut, Storrs, 55 North Eagleville Road, Storrs, CT 06269, USA. 


\section{Acknowledgements}

The authors would like to thank the National Natural Science Foundation of China (Grant Nos: 41171375 and 41571228), the Program for New Century Excellent Talents in University of China (No. NCET-12-0862), the Fok Ying-Tong Education Foundation (No. 141024), the Natural Science Foundation of Hubei Province of China (Grant Nos: 2012FFA031, 2014CFA016), and the Fundamental Research Funds for the Central Universities (Program Nos.: 2662015JQ002, 2013PY029, 2013PY030 and 2010QC036) for financial support. The authors also gratefully acknowledge Dr. Wenfeng Tan and Qiang Lv at Huazhong Agricultural University for insightful suggestions.

\section{Compliance with ethical guidelines}

\section{Competing interests}

The authors declare that they have no competing interests.

Received: 28 November 2014 Accepted: 17 September 2015 Published online: 22 September 2015

\section{References}

1. Li YC, Yu S, Strong J, Wang HL (2012) Are the biogeochemical cycles of carbon, nitrogen, sulfur, and phosphorus driven by the "Fe" $-\mathrm{Fe}$ "I redox wheel" in dynamic redox environments? J Soils Sediments 12:683-693

2. Latta DE, Gorski CA, Scherer MM (2012) Influence of Fe ${ }^{2+}$-catalysed iron oxide recrystallization on metal cycling. Biochem Soc Trans 40:1191-1197

3. Liu H, Wei Y, Sun YH (2005) The formation of hematite from ferrihydrite using Fe(II) as a catalyst. J Mol Catal A-Chem 226:135-140

4. Pedersen HD, Postma D, Jakobsen R, Larsen O (2005) Fast transformation of iron oxyhydroxides by the catalytic action of aqueous Fe(II). Geochim Cosmochim Acta 69:3967-3977

5. Ottley CJ, Davison W, Edmunds WM (1997) Chemical catalysis of nitrate reduction by iron(II). Geochim Cosmochim Acta 61:1819-1828

6. Senn DB, Hemond HF (2002) Nitrate controls on iron and arsenic in an Urban Lake. Science 296:2373-2376

7. Boland DD, Collins RN, Glover CJ, Payne TE, Waite TD (2014) Reduction of $\mathrm{U}(\mathrm{VI})$ by Fe(II) during the Fe(II)-accelerated transformation of ferrihydrite. Environ Sci Technol 48:9086-9093

8. Janzen MP, Nicholson RV, Scharer JM (2000) Pyrrhotite reaction kinetics: Reaction rates for oxidation by oxygen, ferric iron, and for nonoxidative dissolution. Geochim Cosmochim Acta 64:1511-1522

9. Schippers A, Jørgensen BB (2001) Oxidation of pyrite and iron sulfide by manganese dioxide in marine sediments. Geochim Cosmochim Acta 65:915-922

10. Nedel S, Dideriksen K, Christiansen BC, Bovet N, Stipp SLS (2010) Uptake and release of cerium during Fe-oxide formation and transformation in Fe(II) solutions. Environ Sci Technol 44:4493-4498

11. Etique M, Jorand FPA, Zegeye A, Grégoire B, Despas C, Ruby C (2014) Abiotic process for $\mathrm{Fe}(\mathrm{II})$ oxidation and green rust mineralization driven by a heterotrophic nitrate reducing bacteria (Klebsiella mobilis). Environ Sci Technol 48:3742-3751

12. Liu CS, Zhang LJ, Li FB, Wang Y, Gao Y, Li XZ, Cao WD, Feng CH, Dong $J$, Sun L (2009) Dependence of sulfadiazine oxidative degradation on physicochemical properties of manganese dioxides. Ind Eng Chem Res 48:10408-10413

13. Post JE (1999) Manganese oxide minerals: crystal structures and economic and environmental significance. Proc Natl Acad Sci 96:3447-3454

14. Villalobos M, Bargar J, Sposito G (2005) Mechanisms of Pb(II) sorption on a biogenic manganese oxide. Environ Sci Technol 39:569-576

15. Wan SL, Ma MH, Lv L, Qian LP, Xu SY, Xue Y, Ma ZZ (2014) Selective capture of thallium(I) ion from aqueous solutions by amorphous hydrous manganese dioxide. Chem Eng J 239:200-206

16. Zhu MQ, Ginder-Vogel M, Sparks DL (2010) Ni(II) sorption on biogenic Mn-oxides with varying Mn octahedral layer structure. Environ Sci Technol 44:4472-4478

17. Zee CVD, Slomp CP, Rancourt DG, Lange GJD, Raaphorst WV (2005) A Mössbauer spectroscopic study of the iron redox transition in eastern Mediterranean sediments. Geochim Cosmochim Acta 69:441-453
18. Koch DFA (1957) Kinetics of the reaction between manganese dioxide and ferrous ion. Aust J Chem 10:150-159

19. Manceau A, Kersten M, Marcus MA, Geoffroy N, Granina L (2007) Ba and $\mathrm{Ni}$ speciation in a nodule of binary $\mathrm{Mn}$ oxide phase composition from Lake Baikal. Geochim Cosmochim Acta 71:1967-1981

20. Postma D (1985) Concentration of $\mathrm{Mn}$ and separation from Fe in sediments-I. Kinetics and stoichiometry of the reaction between birnessite and dissolved Fe(II) at $10^{\circ} \mathrm{C}$. Geochim Cosmochim Acta 49:1023-1033

21. Rennert T, Pohlmeier R, Mansfeldt T (2005) Oxidation of ferrocyanide by birnessite. Environ Sci Technol 39:821-825

22. Postma D, Appelo CAJ (2000) Reduction of Mn-oxides by ferrous iron in a flow system: column experiment and reactive transport modeling. Geochim Cosmochim Acta 64:1237-1247

23. Siebecker M, Madison AS, Luther GW (2015) Reduction kinetics of polymeric (soluble) manganese (IV) oxide $\left(\mathrm{MnO}_{2}\right)$ by ferrous iron $\left(\mathrm{Fe}^{2+}\right)$. Aquat Geochem 21:143-158

24. Xu Y, Boonfueng T, Axe L, Maeng S, Tyson T (2006) Surface complexation of $\mathrm{Pb}(\mathrm{II})$ on amorphous iron oxide and manganese oxide: spectroscopic and time studies. J Colloid Interf Sci 299:28-40

25. Xu Y, Axe L, Boonfueng T, Tyson TA, Trivedi P, Pandya K (2007) Ni(II) complexation to amorphous hydrous ferric oxide: an X-ray absorption spectroscopy study. J Colloid Interf Sci 314:10-17

26. Ebinger MH, Schulze DG (1989) Mn-substituted goethite and Fe-substituted groutite synthesized at acid pH. Clays Clay Miner 37:151-156

27. Namgung S, Kwon MJ, Qafoku NP, Lee G (2014) $\mathrm{Cr}(\mathrm{OH})_{3}(\mathrm{~s})$ oxidation induced by surface catalyzed Mn(II) oxidation. Environ Sci Technol 48:10760-10768

28. Gao TY, Shi Y, Liu F, Zhang YS, Feng XH, Tan WF, Qiu GH (2015) Oxidation process of dissolvable sulfide by synthesized todorokite in aqueous systems. J Hazard Mater 290:106-116

29. Mckenzie RM (1971) The synthesis of birnessite, cryptomelane, and some other oxides and hydroxides of manganese. Mineral Mag 38:493-502

30. Hem JD (1981) Rates of manganese oxidation in aqueous systems. Geochim Cosmochim Acta 45:1369-1374

31. Ishikawa T, Takeuchi K, Kandori K, Nakayama T (2005) Transformation of $\gamma$-FeOOH to $\alpha-F e O O H$ in acidic solutions containing metal ions. Colloid Surface A 266:155-159

32. Schwertmann U, Taylor RM (1972) The influence of silicate on the transformation of lepidocrocite to goethite. Clays Clay Miner 20:159-164

33. Lu P, Nuhfer NT, Kelly S, Li Q, Konishi H, Elswick E, Zhu C (2011) Lead coprecipitation with iron oxyhydroxide nano-particles. Geochim Cosmochim Acta 75:4547-4561

34. Kim JG, Dixon JB, Chusuei CC, Deng YJ (2002) Oxidation of chromium(III) to $(\mathrm{VI})$ by manganese oxides. Soil Sci Soc Am J 66:306-315

35. Zhao W, Liu F, Feng XH, Tan WF, Qiu GH, Chen XH (2012) Fourier transform infrared spectroscopy study of acid birnessites before and after $\mathrm{Pb}^{2+}$ adsorption. Clay Miner 47:191-204

36. Weckler B, Lutz HD (1998) Lattice vibration spectra. Part XCV. Infrared spectroscopic studies on the iron oxide hydroxides goethite $(\alpha)$, akaganéite $(\beta)$, lepidocrocite $(\gamma)$, and feroxyhite $(\delta)^{1}$. Eur J Solid State Inorg Chem 35:531-544

37. Barrón V, Torrent J (2002) Evidence for a simple pathway to maghemite in Earth and Mars soils. Geochim Cosmochim Acta 66:2801-2806

38. Liu H, Li P, Zhu MY, Wei Y, Sun YH (2007) Fe(II)-induced transformation from ferrihydrite to lepidocrocite and goethite. J Solid State Chem 180:2121-2128

39. Schippers A, Neretin LN, Lavik G, Leipe T, Pollehne F (2005) Manganese(II) oxidation driven by lateral oxygen intrusions in the western Black Sea. Geochim Cosmochim Acta 69:2241-2252

40. Straub KL, Schönhuber WA, Buchholz-Cleven BEE, Schink B (2004) Diversity of ferrous iron-oxidizing, nitrate-reducing bacteria and their involvement in oxygen-independent iron cycling. Geomicrobiol J 21:371-378

41. Qiu GH, Li Q, Yu Y, Feng XH, Tan WF, Liu F (2011) Oxidation behavior and kinetics of sulfide by synthesized manganese oxide minerals. J Soils Sediments 11:1323-1333

42. Herszage J, Afonso MD (2003) Mechanism of hydrogen sulfide oxidation by manganese(IV) oxide in aqueous solutions. Langmuir 19:9684-9692 
43. Landrot G, Ginder-Vogel M, Sparks DL (2010) Kinetics of chromium(III) oxidation by manganese(IV) oxides using quick scanning $X$-ray absorption fine structure spectroscopy (Q-XAFS). Environ Sci Technol 44:143-149

44. Han RP, Lu ZW, Zou H, Wang DT, Shi J, Yang JJ (2006) Removal of copper(II) and lead(II) from aqueous solution by manganese oxide coated sand II. Equilibrium study and competitive adsorption. J Hazard Mater B 137:480-488
45. Loganathan P, Burau RG, Fuerstenau DW (1977) Influence of $\mathrm{pH}$ on the sorption of $\mathrm{Co}^{2+}, \mathrm{Zn}^{2+}$ and $\mathrm{Ca}^{2+}$ by a hydrous manganese oxide. Soil Sci Soc Am J 41:57-62

46. Roekens EJ, Grieken REV (1983) Kinetics of iron oxidation in seawater of various pH. Mar Chem 13:195-202

\section{Publish with ChemistryCentral and every scientist can read your work free of charge}

"Open access provides opportunities to our colleagues in other parts of the globe, by allowing anyone to view the content free of charge."

W. Jeffery Hurst, The Hershey Company.

- available free of charge to the entire scientific community

- peer reviewed and published immediately upon acceptance

- cited in PubMed and archived on PubMed Central

- yours - you keep the copyright

Submit your manuscript here:

http://www.chemistrycentral.com/manuscript/

ChemistryCentral 